\title{
Thyroid hormone metabolism in innate immune cells
}

\author{
Anne H van der Spek, Eric Fliers and Anita Boelen
}

Department of Endocrinology and Metabolism, Academic Medical Center, Amsterdam, The Netherlands

Correspondence should be addressed to A Boelen

Email

a.boelen@amc.uva.nl

\begin{abstract}
Thyroid hormone (TH) metabolism and thyroid status have been linked to various aspects of the immune response. There is extensive literature available on the effects of thyroid hormone on innate immune cells. However, only recently have authors begun to study the mechanisms behind these effects and the role of intracellular TH metabolism in innate immune cell function during inflammation. This review provides an overview of the molecular machinery of intracellular TH metabolism present in neutrophils, macrophages and dendritic cells and the role and effects of intracellular TH metabolism in these cells. Circulating TH levels have a profound effect on neutrophil, macrophage and dendritic cell function. In general, increased TH levels result in an amplification of the pro-inflammatory response of these cells. The mechanisms behind these effects include both genomic and non-genomic effects of TH. Besides a pro-inflammatory effect induced by extracellular $\mathrm{TH}$, the cellular response to pro-inflammatory stimuli appears to be dependent on functional intracellular TH metabolism. This is illustrated by the fact that the deiodinase enzymes and in some cell types also thyroid hormone receptors appear to be crucial for adequate innate immune cell function. This overview of the literature suggests that TH metabolism plays an important role in the host defence against infection through the modulation of innate immune cell function.
\end{abstract}

Journal of Endocrinology (2017) 232 R67-R81

\section{Introduction}

The interplay between the endocrine and immune system is well established (Besedovsky \& del Rey 1996, Klein 2006, Schaefer \& Klein 2011). Thyroid hormone (TH) metabolism and $\mathrm{TH}$ status have been linked to various aspects of the immune response (Boutzios \& Kaltsas 2000, Klein 2006, De Vito et al. 2011), and there is an extensive body of literature available on the effects of TH on various types of innate immune cells (De Vito et al. 2011). However, very few of these studies analyse the mechanisms behind the effects of $\mathrm{TH}$ or the role of intracellular $\mathrm{TH}$ metabolism in innate immune cells. In recent years, the role of $\mathrm{TH}$ metabolism in innate immune cell function has been studied in more detail, and it has been suggested that innate immune cells are important $\mathrm{T}_{3}$ target cells and that intracellular TH plays an essential role in the function of several cell types of the innate immune system. This review provides an overview of the elements of intracellular $\mathrm{TH}$ metabolism present in innate immune cells and the role and effects of intracellular TH metabolism in these cells. It focuses specifically on the phagocytic innate immune cells: neutrophils, macrophages and dendritic cells.

\section{Thyroid hormone production and metabolism}

The regulation of plasma $\mathrm{TH}$ levels is conducted via a classic endocrine negative feedback loop involving

Published by Bioscientifica Ltd. 
the hypothalamic-pituitary-thyroid (HPT) axis. Hypophysiotropic neurons within the paraventricular nucleus of the hypothalamus produce thyrotropinreleasing hormone (TRH), which in turn stimulates the thyrotroph cells of the anterior pituitary to synthesize and secrete thyroid-stimulating hormone (TSH) (Harris et al. 1978). TSH then stimulates the thyroid gland to produce thyroid hormones in the form of thyroxine $\left(\mathrm{T}_{4}\right)$ and triiodothyronine $\left(\mathrm{T}_{3}\right)$ (Miot et al. 2015). These hormones are secreted into the circulation, and their plasma levels in turn regulate the hypothalamic release of TRH, completing the feedback loop.

The thyroid gland mainly produces $\mathrm{T}_{4}$, which functions as a prohormone and requires conversion to $\mathrm{T}_{3}$ to become biologically active, although a minor role for direct actions of $\mathrm{T}_{4}$ has also been reported (Davis et al. 2016). This conversion occurs at the cellular and tissue level, enabling the local regulation of TH bioavailability.

\section{Intracellular thyroid hormone metabolism}

$\mathrm{TH}$ is actively transported into the cell by TH transporters. There are several families of $\mathrm{TH}$ transporters including organic anion transporter polypeptides (OATP), monocarboxylate transporters (MCT) and large neutral amino acid transporters (LAT) (Bernal et al. 2015, Visser 2016). Of these transporters, MCT8 is the only one to transport $\mathrm{TH}$ exclusively. The other transporters are also capable of transporting additional substances including steroids and amino acids (Bernal et al. 2015). Studies on transgenic mouse models and observations in patients with pathogenic mutations in $\mathrm{TH}$ transporters indicate that MCT8, MCT10 and OATP1C1 are the main transporters of (patho)physiological importance to TH transport in vivo (Bernal et al. 2015, Visser 2016). MCT8 preferentially transports $\mathrm{T}_{4}$, whereas MCT10 preferentially transports $\mathrm{T}_{3}$ (Visser 2016). OATP1C1 transports $\mathrm{T}_{3}, \mathrm{~T}_{4}$ and $\mathrm{rT}_{3}$ with high specificity; however, it has the lowest affinity for $\mathrm{T}_{4}$ out of these transporters (Pizzagalli et al. 2002, Bernal et al. 2015, Visser 2016). Transporter expression is cell type-specific and differences in distribution have been observed between humans and rodents (Bernal et al. 2015).

After being transported into the cell, TH is metabolized by the iodothyronine deiodinases. This a family of enzymes that remove an iodine atom from the phenolic or tyrosyl ring of TH (Bianco \& Kim 2006, Visser \& Peeters 2012). Type 1 deiodinase (D1) is capable of both inner and outer ring deiodination. Although it has a lower affinity for $\mathrm{T}_{4}$ than the other deiodinases, it is highly expressed in the liver where it is thought to be the main source of local $\mathrm{T}_{3}$ and to be important for the clearance of $\mathrm{rT}_{3}$ (Bianco \& Kim 2006). Type 2 deiodinase (D2) is capable of phenolic or outer ring deiodination resulting in the conversion of the prohormone $\mathrm{T}_{4}$ to the active hormone $\mathrm{T}_{3}$ (Bianco \& Kim 2006). Approximately $80 \%$ of extra-thyroidal $T_{3}$ is derived from peripheral deiodination of $\mathrm{T}_{4}$, mainly by $\mathrm{D} 1$ in the liver and D2 in skeletal muscle (Visser \& Peeters 2012). Type 3 deiodinase (D3) is an inner ring deiodinase that converts $T_{4}$ and $T_{3}$ to their respective inactive metabolites $\mathrm{rT}_{3}$ and $\mathrm{T}_{2}$ (Bianco \& Kim 2006).

Besides deiodination, there are other minor pathways of $\mathrm{TH}$ metabolism including sulfation, glucaronidation and ether-linked cleavage. The precise mechanisms of these metabolic pathways are beyond the scope of this review and have been discussed by other authors in more detail (Wu et al. 2005, Visser \& Peeters 2012).

The classical pathway through which $\mathrm{TH}$ exerts its biological effects is by binding to the nuclear TH receptors (TRs). Upon binding of $\mathrm{T}_{3}$, these TRs are capable of directly initiating or inhibiting gene transcription (Brent 2012, Mullur et al. 2014). There are several TR isoforms that are differentially expressed in a tissue- and cell type-specific manner (Brent 2012). The isoforms that are capable of binding $\mathrm{T}_{3}$ are $\mathrm{TR} \alpha 1$, which is widely expressed in cardiac and skeletal muscle, the central nervous system and bone, TR $\beta 1$, which is mainly present in the brain, liver and kidney and TR $\beta 2$, which is expressed in the hypothalamus and pituitary (Cheng et al. 2010, Brent 2012).

There is increasing evidence that THs also act via non-genomic pathways (Davis et al. 2016). The pathways involved in non-genomic $\mathrm{TH}$ actions are initiated by binding of $\mathrm{TH}$ to another receptor than the intracellular TRs, for example to the receptor on plasma membrane integrin $\alpha v \beta 3$ (Davis et al. 2016). The classic pathways of $\mathrm{TH}$ action and the rapid non-genomic pathways activated by $\mathrm{TH}$ are not completely independent from each other as rapid non-genomic actions of $\mathrm{TH}$ can affect intracellular TRs and even require TRs in certain cell types (Davis et al. 2016, Flamant 2016).

\section{Innate immune cells}

The innate immune system is responsible for the host defence against invading pathogens. The cells of the innate immune system identify microbes, initiate an inflammatory response and can either directly phagocytose and kill pathogens or recruit other innate

Published by Bioscientifica Ltd. 
or adaptive immune cells to the site of infection. Innate immune cells are derived from haematopoietic stem cells in the bone marrow. These cells can be mobilized from the blood or bone marrow upon infection. Alternatively, innate immune cells travel from the bone marrow to the tissue and patrol there for invading pathogens; these are known as tissue-resident cells. This review will focus on the phagocytic innate immune cells, which comprise neutrophils, monocytes/macrophages and dendritic cells.

\section{Neutrophils}

Neutrophils are the first cells to be recruited to the site of inflammation and are the most abundant type of blood leukocyte, comprising 50-75\% of circulating leukocytes in humans (Borregaard 2010, Kolaczkowska \& Kubes 2013, Bardoel et al. 2014). Circulating neutrophils are short-lived cells that are generated in the bone marrow by haematopoietic stem cells (Borregaard 2010).

Upon inflammation and infection, neutrophils from the circulation are recruited to the site of inflammation. Inflammatory mediators are recognised by neutrophils, after which they adhere to the vascular endothelium close to the site of infection before transmigrating into the extravascular tissue. Extravasated neutrophils then migrate to the place of inflammation where they can then kill invading pathogens and secrete inflammatory mediators further stimulating the immune response and recruiting other innate and adaptive immune cells (Kolaczkowska \& Kubes 2013).

Neutrophils are highly specialized cells that have multiple microbial killing mechanisms at their disposal. These mechanisms have been discussed extensively in other reviews (Borregaard 2010, Kolaczkowska \& Kubes 2013, Bardoel et al. 2014), therefore, we will only include a brief overview of these processes here. The three main killing mechanisms utilized by neutrophils are degranulation, the production of reactive oxygen species and the generation of neutrophil extracellular traps (Kolaczkowska \& Kubes 2013, Bardoel et al. 2014). Upon phagocytosis of a pathogen, neutrophils can release various bactericidal elements into the phagosome. Some of these elements are antimicrobial proteins and enzymes that are formed sequentially during neutrophil development and stored in intracellular granules (Borregaard \& Cowland 1997, Borregaard 2010). Upon phagocytosis, these granules can fuse with the phagosome or the plasma membrane, releasing their contents in a process known as degranulation (Borregaard 2010). Neutrophils are also capable of generating reactive oxygen species (ROS) in the phagosome using the nicotinamide adenine dinucleotide phosphate (NADPH) oxidase system. An important extracellular killing mechanism is neutrophil extracellular traps (NETs) (Brinkmann et al. 2004). NETs are composed of neutrophil chromatin to which antimicrobial proteins and ROS are bound (Brinkmann et al. 2004, Kolaczkowska \& Kubes 2013). The release of these NETs enables neutrophils to effectively trap and kill extracellular bacteria, but also eventually results in the death of the neutrophil (Brinkmann et al. 2004).

\section{Monocytes and macrophages}

Monocytes and macrophages are mononuclear phagocytic cells. Monocytes are continuously generated in the bone marrow by haematopoiesis and released into the circulation where they constitute 10\% of circulating human leukocytes. There is also a considerable monocyte reservoir in the spleen and lungs that can be mobilized on demand (Ginhoux \& Jung 2014). Circulating monocytes can extravasate to tissues both during the steady state and during inflammation where they can differentiate into macrophages or dendritic cells (Shi \& Pamer 2011). An alternative subset of macrophages is the tissue-resident macrophages. Until recently, these were thought to be continuously replenished from the circulating monocyte pool. Tissue-resident macrophages are now known to be derived from embryonic precursors that colonize the tissues prenatally (Mass et al. 2016). These cells, which include Kupffer cells and microglia, are also able to maintain their populations in adult tissues due to local cell proliferation independently of circulating monocytes (Hashimoto et al. 2013, Ginhoux \& Jung 2014, Mass et al. 2016). The various tissue-resident macrophages comprise distinct cell populations whose phenotype differs strongly between tissues (Murray \& Wynn 2011).

After entering the tissue, macrophages can change their phenotype due to various stimuli, allowing them to adapt to a wide subset of roles. This process is known as polarization. Polarized macrophages are generally classified into M1 or classically activated macrophages, which are pro-inflammatory cells, and M2 or alternatively activated macrophages, which is a heterogeneous group of cells that have a more anti-inflammatory profile (Murray \& Wynn 2011). M1 macrophages are important in antimicrobial defence and the recruitment of neutrophils and T cells to the inflamed tissue (Murray \& Wynn 2011). They are also capable of antigen presentation and can 
elicit a T-cell response (Hume 2008). M1 polarization is accompanied by changes in cellular metabolism, shifting towards enhanced glycolysis (Freemerman et al. 2014, Galvan-Pena \& O'Neill 2014, Zhu et al. 2015). Essential components of adequate pro-inflammatory macrophage function are phagocytosis, the generation of ROS by NADPH oxidase and the generation of reactive nitrogen species (RNS), which is mediated by inducible nitric oxide synthase (iNOS) (Weiss \& Schaible 2015). M2 macrophages are tolerogenic and immunomodulatory cells that are involved in wound healing and tissue remodelling (Murray \& Wynn 2011). This is also accompanied by metabolic changes resulting in enhanced fatty acid oxidation and mitochondrial oxidative phosphorylation (Vats et al. 2006, Galvan-Pena \& O’Neill 2014, Zhu et al. 2015). More recent data suggest that macrophage polarization is not as clear cut as these two phenotypes and represents more of a spectrum ranging from pro- to anti-inflammatory (Hume 2015).

\section{Dendritic cells}

Dendritic cells are unique innate immune cells that are not only capable of phagocytosing pathogens but also function as antigen-presenting cells. Dendritic cells thus bridge the gap between innate and adaptive immunity and can shape the T-cell response. The dendritic cell (DC) population is derived from the haematopoietic lineage and is more heterogeneous than previously thought. Currently four main types of DCs are recognised: classic DCs, plasmacytoid DCs, Langerhans cells and monocytederived DCs. All these subsets derive from a common myeloid progenitor (Satpathy et al. 2012, Pearce \& Everts 2015). Classic DCs and monocyte-derived DCs are cells specialized in phagocytosis of pathogens. Unstimulated or immature classic DCs have a short half-life and are continuously replenished from precursors in the bone marrow (Satpathy et al. 2012). After activation these cells undergo considerable morphological changes and are characterized as mature classic DCs. Just as in macrophages, the activation of DCs is accompanied by a shift in cellular metabolism favouring glycolysis over oxidative phosphorylation (Pearce \& Everts 2015). Mature DCs are capable of migrating to lymph nodes and subsequent antigen presentation to $\mathrm{T}$ cells, initiating and shaping the adaptive immune response. Plasmacytoid DCs are not phagocytic and inefficient at antigen presentation. They are thought to play an important role in the immune response to viruses as they produce large amounts of type 1 interferon upon viral encounter. Langerhans cells are tissue-resident DCs in the skin that resemble tissueresident macrophages in many ways but are also capable of migrating to lymphoid tissues (Satpathy et al. 2012, Pearce \& Everts 2015).

\section{Thyroid hormone metabolism in neutrophils}

\section{Intracellular thyroid hormone metabolism in neutrophils}

Neutrophils contain essential elements required for intracellular TH metabolism and action. Murine neutrophils contain the TH transporter MCT8, whereas human neutrophils express MCT10 but not MCT8 mRNA (Boelen et al. 2005, van der Spek et al. 2016). It has long been known that activated neutrophils are capable of deiodinating both $\mathrm{T}_{3}$ and $\mathrm{T}_{4}$ (Woeber 1971, 1978, Woeber et al. 1972, Klebanoff \& Green 1973, Woeber \& Ingbar 1973). Research from the seventies already found that phagocytosing human neutrophils can generate both $\mathrm{T}_{3}$ and $\mathrm{rT}_{3}$ from $\mathrm{T}_{4}$ and that this deiodinating activity was mainly present in the granule fraction of the cells (Woeber 1976, 1978). Neutrophils were also shown to contain saturable nuclear-binding sites for $T_{3}$ (Woeber 1977). It has since been found that type 3 deiodinase (D3), the TH-inactivating enzyme, is present in both human and murine neutrophils and is located in the cytosol and in bactericidal granules within the cell (Boelen et al. 2005, 2008, van der Spek et al. 2016). Human neutrophils were also recently shown to express type 1 deiodinase (D1) and TR $\alpha 1$ at the transcriptional level (van der Spek et al. 2016).

\section{Effects of thyroid hormones on neutrophil function}

Neutrophil bacterial killing can be mediated by a number of different mechanisms one of which is the generation of reactive oxygen species (ROS) by the NADPH oxidase system (Kolaczkowska \& Kubes 2013). Circulating TH levels affect ROS generation by stimulated neutrophils. Hyperthyroidism results in increased ROS generation by stimulated neutrophils ex vivo compared to cells from euthyroid controls, whereas hypothyroidism has the opposite effect and limits neutrophil ROS generation. This has been demonstrated in neutrophils from hypothyroid and hyperthyroid rats (Videla et al. 1993, Fernandez \& Videla 1995) and hyperthyroid and hypothyroid patients (Videla et al. 1993, Szabo et al. 1996, Russo-Carbolante et al. 2005b, Marino et al. 2006) or healthy controls with experimentally induced hyperthyroidism (Magsino et al. 2000). In both hypothyroidism and

Published by Bioscientifica Ltd 
hyperthyroidism, the changes in neutrophil ROS generation are (partially) reversed by restoring $\mathrm{TH}$ levels to within the normal range (Videla et al. 1993, Marino et al. 2006).

Although studies using cells derived from hyperthyroid or hypothyroid patients and animals all find similar effects of TH levels on ROS generation, the effects of in vitro incubation of neutrophils with TH are less consistent. Some authors find that in vitro TH stimulation increases neutrophil ROS generation (Mezosi et al. 2005), whereas others only find an effect for supraphysiological levels of $\mathrm{T}_{4}$ (Marino et al. 2006). In contrast, a decrease in ROS generation after TH incubation (Aoyagi et al. 1991) or no effect at all has also been reported (Videla et al. 1993). These conflicting results suggest that the effects of TH on neutrophil ROS generation cannot be entirely explained by direct effects of TH on these cells. The link between TH metabolism and oxidative stress that occurs outside innate immune cells has been reviewed elsewhere and is beyond the scope of this review (Mancini et al. 2016).
Another important neutrophil-killing mechanism is the use of antibacterial proteins housed in granules within the cell (Kolaczkowska \& Kubes 2013). One of these proteins is myeloperoxidase (MPO). The only two studies to assess the effect of TH levels on MPO both find an increase in MPO activity in neutrophils either derived from hyperthyroid animals (Fernandez \& Videla 1995) or incubated with TH in vitro (Mezosi et al. 2005).

Circulating TH levels appear to have a clear effect on neutrophil function. Mezosi and coworkers found that these effects were mediated via non-genomic pathways. The increase in neutrophil ROS production elicited by $\mathrm{TH}$ incubation in vitro was partially mediated via an unknown G-protein-coupled receptor and dependent on signalling through the protein kinase $\mathrm{C}$ pathway and increased intracellular $\mathrm{Ca}^{2+}$ levels (Fig. 1) (Mezosi et al. 2005). Hyperthyroidism did not affect superoxide dismutase activity and glutathione content indicating that the increase in ROS generation found was not due to changes in antioxidant defences (Russo-Carbolante et al. 2005b).

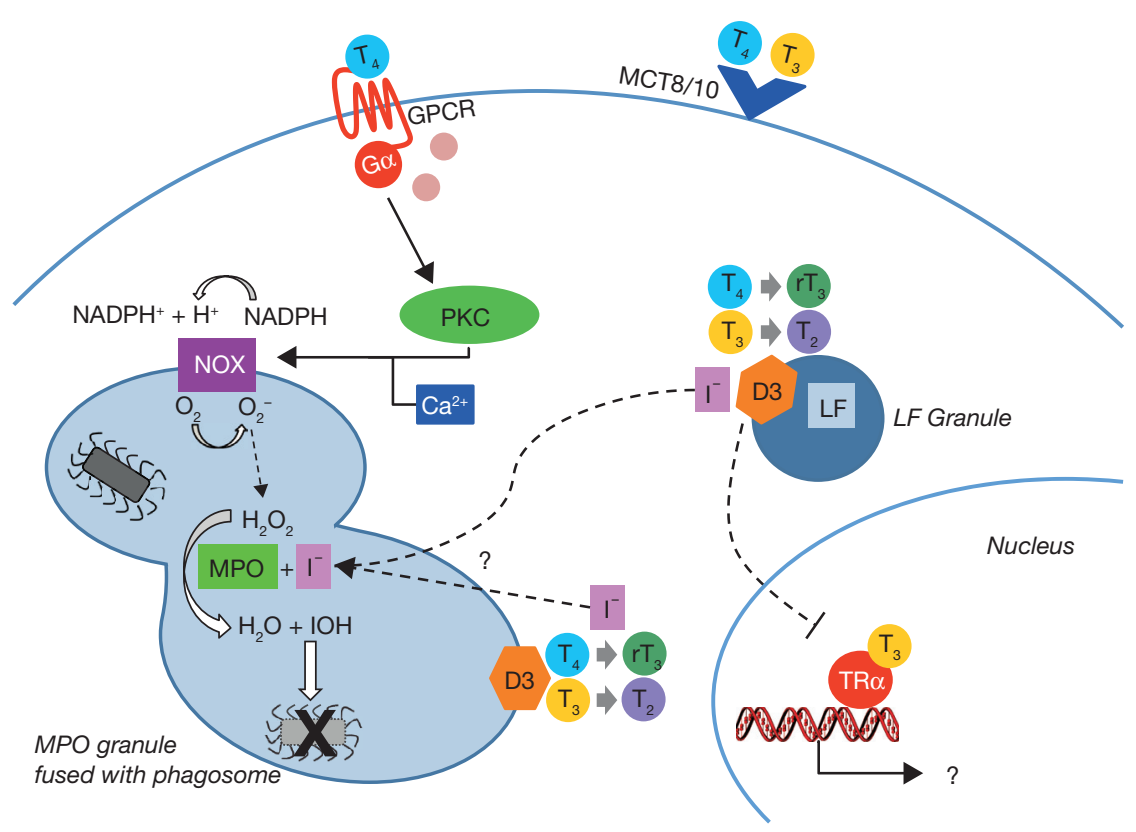

Figure 1

Hypothetical pathways explaining the effects of thyroid hormone on neutrophil NAPDH oxidase activity and bacterial killing. Thyroid hormone induces neutrophil NADPH oxidase (NOX) activity, resulting in increased production of reactive oxygen species. This phenomenon is thought to be mediated via a non-genomic pathway involving binding of TH to a G-protein-coupled receptor (GPCR), which induces NAPDH oxidase activity. This effect is dependent on protein kinase C (PKC) and adequate intracellular $\mathrm{Ca}^{2+}$ levels (Mezosi et al. 2005). Intracellular thyroid hormone metabolism may also play a role in neutrophils during bacterial killing. The thyroid hormone-inactivating type 3 deiodinase (D3) is present in murine and human neutrophils (Boelen et al. 2005, 2008, van der Spek et al. 2016). Mice that lack this enzyme suffer from impaired bacterial killing (Boelen et al. 2009). D3 is located in the cytoplasm and in granules containing either myeloperoxidase (MPO) or lactoferrin (LF) (van der Spek et al. 2016). TH enters the neutrophil via transporters (MCT8 or MCT10) where it is inactivated by D3, which removes an iodine atom from the inner ring of the hormone, converting $\mathrm{T}_{4}$ to reverse (r) $\mathrm{T}_{3}$ and $\mathrm{T}_{3}$ to $\mathrm{T}_{2}$. Increased D3 activity therefore results in decreased intracellular levels of $\mathrm{T}_{3}$ together with the production of free iodide (I-). One hypothesis explaining the role of D3 in microbial killing is that the iodide produced by D3 is utilized by MPO together with hydrogen peroxidase $\left(\mathrm{H}_{2} \mathrm{O}_{2}\right)$ to generate hypoiodite $(\mathrm{IOH})$, a toxic compound that is capable of killing bacteria (Klebanoff 1967, Boelen et al. 2011). The reduction of intracellular $\mathrm{T}_{3}$ levels could theoretically also result in altered gene transcription, but no TH-responsive genes have been found in neutrophils yet.

http://joe.endocrinology-journals.org DOI: $10.1530 / \mathrm{JOE}-16-0462$
๑) 2017 Society for Endocrinology Printed in Great Britain
Published by Bioscientifica Ltd. 


\section{Role of intracellular thyroid hormone metabolism in neutrophil function}

Besides the effects of circulating TH levels on neutrophils, intracellular TH metabolism appears to play an essential role in neutrophil function during infection and inflammation.

THs are drawn to the site of bacterial infection (Adelberg et al. 1971). Activated phagocytosing neutrophils are capable of cleavage of thyroxinebinding globulin (TBG), thus increasing the amount of extracellularly available $\mathrm{T}_{4}$ (Jirasakuldech et al. 2000). As mentioned previously, phagocytosing neutrophils also metabolize significant amounts of TH (Woeber 1971, 1978, Woeber et al. 1972, Klebanoff \& Green 1973, Woeber \& Ingbar 1973). This suggests that TH metabolism plays an important role in infiltrating neutrophils during infection.

Most authors find that metabolism of $\mathrm{TH}$ by phagocytosing neutrophils results in the production of inorganic iodide, suggesting the involvement of the deiodinase enzymes (Woeber et al. 1972, Klebanoff \& Green 1973, Woeber \& Ingbar 1973). Other authors have found that phagocytosing neutrophils are capable of ether-linked cleavage of $\mathrm{T}_{4}$, which results in the formation of diiodotyrosine (DIT) (Burger et al. 1983). The degradation of TH requires the intracellular formation of ROS as neutrophils from patients with chronic granulomatous disease, which is characterized by defective NAPDH oxidase resulting in reduced ROS generation, have significantly impaired ability to degrade TH (Klebanoff \& Green 1973, Woeber \& Ingbar 1973, Burger et al. 1983). Although isolated MPO is capable of degrading $\mathrm{TH}$ in vitro, neutrophils from MPO-deficient patients degrade $\mathrm{TH}$ to the same degree as controls suggesting that the degradation of TH by leukocytes is not MPO dependent in vivo (Klebanoff \& Green 1973, Woeber \& Ingbar 1973, Burger et al. 1983).

Type 3 deiodinase (D3) is expressed in infiltrating murine neutrophils during both bacterial infection and sterile inflammation (Boelen et al. 2005, 2008). It was recently shown to also be present in human neutrophils (van der Spek et al. 2016). In a murine model for chronic local inflammation in which mice were injected with turpentine resulting in the formation of a subcutaneous abscess, D3 activity was strongly elevated in inflamed tissue compared to control tissue (Boelen et al. 2005). Mice that lack D3 have impaired bacterial killing upon infection with Streptococcus pneumoniae (Boelen et al. 2009). D3 in human neutrophils was found in intracellular granules involved in bacterial killing (van der Spek et al. 2016). The enzyme was also found in early-stage neutrophil extracellular traps (NETs) (van der Spek et al. 2016). Together these data suggest that D3 is important for neutrophil function during infection and inflammation. The mechanism behind this is currently unknown. We have previously suggested as a possible explanation that the iodide produced by D3 could be used by the MPO system together with $\mathrm{H}_{2} \mathrm{O}_{2}$ to generate hypoiodite, a toxic compound that is capable of killing bacteria (Fig. 1) (Klebanoff 1967, Boelen et al. 2011).

Type 1 deiodinase is also present in human neutrophils, whereas its expression in murine neutrophils is unknown (van der Spek et al. 2016). D1 could also potentially be a source of iodide for the cells; however, blocking D1 activity by PTU was shown to have no effect on the neutrophil respiratory burst, which is in contrast to the observation that $\mathrm{TH}$ raises neutrophil ROS production (Mezosi et al. 2005, Russo-Carbolante et al. 2005a).

\section{Thyroid hormone metabolism in monocytes and macrophages}

\section{Intracellular thyroid hormone metabolism in macrophages}

Macrophages contain several essential elements of intracellular TH metabolism. Both macrophage cell lines and human and murine microglia contain TH transporters. Macrophage cell lines predominantly express MCT10 and to a lesser extent MCT8 (Kwakkel et al. 2014). Microglia, the resident macrophages of the brain, contain the $\mathrm{TH}$ transporters LAT2, MCT10 and OATP4a1 (Wirth et al. 2009, Braun et al. 2011). Macrophages were also found to express D2 (Kwakkel et al. 2014), TR $\alpha 1$ and possibly also TR $\beta$ although authors have reported conflicting results (Billon et al. 2014, Kwakkel et al. 2014, Lourbopoulos et al. 2014, Perrotta et al. 2014). Several recent papers have demonstrated that both human and murine macrophages are able to produce a functional TSH $\beta$ splice variant that is positively regulated by $\mathrm{T}_{3}$ and capable of stimulating the TSH receptor (Vincent et al. 2009, Baliram et al. 2013, 2016). It has been suggested that this TSH $\beta$ splice variant plays a role in bone physiology; however, whether it affects macrophage function is currently unknown.

\section{Effects of extracellular thyroid hormone levels on macrophage function}

There are several studies available on the effects of $\mathrm{TH}$ administration on macrophage function either in vivo,

Published by Bioscientifica Ltd 
ex vivo or in vitro. The majority of these functional studies assessed pro-inflammatory macrophage function.

Several studies in both human subjects and animal models have found that, similar to neutrophils, stimulated hyperthyroid macrophages have increased ROS production ex vivo (Videla et al. 1993, Magsino et al. 2000) although one study found an opposite effect (Rosa et al. 1995). PTU treatment of hyperthyroid patients normalized ROS production although these findings could not be replicated in vitro (Videla et al. 1993). It should be noted that the majority of these studies assessed a mixed population of mononuclear cells containing significant numbers of other cell types, making it impossible to determine the contribution of the macrophage/monocyte subset. Recently, TH administration was found to increase iNOS expression, nitrite production and in vitro bacterial killing in both a human and a mouse macrophage cell line and treatment with $\mathrm{TH}$ increased the survival after meningococcal infection in mice (Chen et al. 2012).

Macrophage phagocytosis is also affected by TH concentrations with most studies finding that higher levels of available $\mathrm{TH}$ result in an increased phagocytic capacity. Strenuous exercise leads to both increased plasma $\mathrm{TH}$ levels and increased macrophage phagocytosis (Forner et al. 1996, Ortega et al. 1996). This effect was confirmed in vitro where incubation of
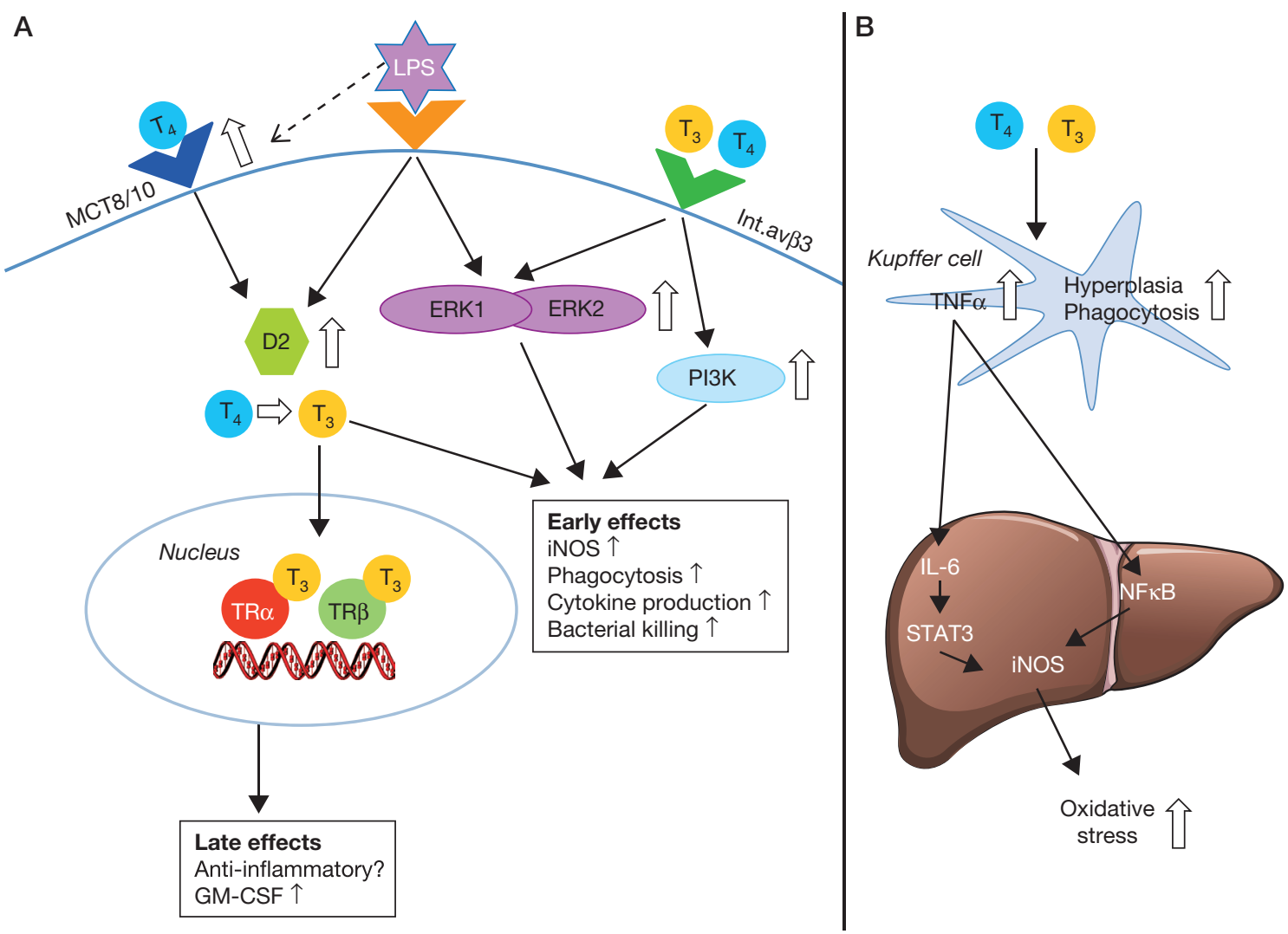

Figure 2

Thyroid hormone induces a pro-inflammatory response in macrophages. (A) The effects of TH in macrophages are mediated through integrin $\alpha \mathrm{v} \beta 3$ or through modulation of intracellular TH levels. TH can bind to integrin $\alpha \mathrm{v} \beta 3$ on the macrophage cell surface resulting in the activation of PI3K and ERK $1 / 2$ pathways followed by the upregulation of inducible nitric oxide synthase (iNOS) (Chen et al. 2012). Alternatively, TH can enter the cell through TH transporters MCT8 or MCT10 after which the prohormone $\mathrm{T}_{4}$ is converted to active hormone $\mathrm{T}_{3}$ by type 2 deiodinase (D2) resulting in increased phagocytosis and cytokine response. D2 is induced in lipopolysaccharide (LPS)-stimulated macrophages (Kwakkel et al. 2014). The effects of intracellular $\mathrm{T}_{3}$ are partly mediated via TR $\alpha$, which is required for adequate macrophage function (Billon et al. 2014, Kwakkel et al. 2014). Low-grade inflammation found in unstimulated TR $\alpha$-knockout macrophages suggests that TR $\alpha$ possibly attenuates the rapid pro-inflammatory response generated by increased intracellular TH levels (Billon et al. 2014). (B) Kupffer cells are the resident macrophages of the liver. TH stimulation in vivo results in Kupffer cell hyperplasia and enhanced phagocytosis (Tapia et al. 1997, Valencia et al. 2004). TH transporter and receptor expression in Kupffer cells have not yet been studied. TH also increases the production of TNF $\alpha$ by Kupffer cells (Valencia et al. 2004, Fernandez et al. 2005, 2007b). TNF $\alpha$ produced by Kupffer cells results in liver NFKB activation (Valencia et al. 2004). IL-6 production is also increased, resulting in increased STAT3 activation (Tapia et al. 2006). The activation of both these pathways results in increased iNOS activity in the liver, resulting in the production of larger amounts of reactive oxygen species and hepatic oxidative stress (Fernandez et al. 2005). 
murine peritoneal macrophages with $\mathrm{TH}$ also resulted in increased phagocytosis and chemotaxis (Forner et al. 1996, Ortega et al. 1996, 1999). Notably, a 10,000-fold greater concentration of TH did not affect macrophage function, suggesting that this effect is only present at physiological levels (Forner et al. 1996, Ortega et al. 1999). One study found an opposite effect on phagocytosis with macrophages from hypothyroid animals demonstrating higher phagocytosis and no effect of hyperthyroidism on phagocytic capacity (Rosa et al. 1995).

The generally observed pro-inflammatory effect of $\mathrm{TH}$ administration on macrophages suggests a shift towards an M1 phenotype. Incubation with $\mathrm{T}_{3}$ indeed polarizes bone marrow-derived murine macrophages towards a pro-inflammatory M1 phenotype and inhibits M2 polarization (Perrotta et al. 2014). Polarization was accompanied by a change in $\operatorname{TR} \alpha_{1}: \operatorname{TR} \beta_{1}$ ratio, suggesting that perhaps relative abundance of TR isoforms is associated with macrophage phenotype (Perrotta et al. 2014). It should be noted that these effects were achieved by incubating cells with supraphysiological levels of $T_{3}$ $(500 \mathrm{nM})$; therefore, these results are in contrast with the studies mentioned previously that find no effect of supraphysiological TH levels (Forner et al. 1996, Ortega et al. 1999). This could be explained by the degree of excess: $500 \mathrm{nM}$ is an approximately 250 -fold higher concentration than circulating $\mathrm{T}_{3}$ in euthyroid mice, whereas Forner and coworkers and Ortega and coworkers used a 10,000-fold higher concentration.

\section{Role of intracellular thyroid hormone metabolism in macrophage function}

Although the effects of extracellular thyroid hormone concentrations on macrophages are reasonably well characterized, the role of specific elements of intracellular TH metabolism in these effects has only recently been studied. The results indicate that adequate regulation of intracellular TH levels affects macrophage function via a combination of genomic and non-genomic pathways. The TH-induced increase in iNOS expression and activity, phagocytosis and bacterial killing is thought to be partly mediated via binding of $\mathrm{TH}$ to integrin $\alpha \mathrm{v} \beta 3$ on the extracellular surface of the cell, which results in the rapid activation of the PI3K and ERK1/2 signalling pathways (Fig. 2A) (Chen et al. 2012).

Besides the extracellular binding of $\mathrm{TH}$, regulation of intracellular TH levels was also recently shown to play an essential role in the pro-inflammatory response of macrophages (Kwakkel et al. 2014). D2, which converts $\mathrm{T}_{4}$ to $\mathrm{T}_{3}$ thereby regulating intracellular $\mathrm{TH}$ bioavailability, is induced in macrophages stimulated with bacterial endotoxin (lipopolysaccharide; LPS) together with TR $\alpha 1$ and MCT10, indicating a shift towards increased $\mathrm{TH}$ action during inflammation (Fig. 2A) (Kwakkel et al. 2014). Furthermore, D2 knockdown resulted in impaired macrophage phagocytosis and blunted cytokine response to LPS stimulation (Kwakkel et al. 2014). These effects appear to be partly mediated via genomic pathways as knockout of TR $\alpha$, which is the predominant TR isoform in macrophages, also results in aberrant macrophage function (Billon et al. 2014, Kwakkel et al. 2014). Macrophages from TR $\alpha$-knockout mice have impaired cholesterol efflux during atherosclerosis resulting in earlier plaque formation (Billon et al. 2014). Furthermore, macrophages that lack TR $\alpha$ demonstrate low-grade inflammation at baseline compared to controls, indicating an anti-inflammatory role for TR $\alpha$ (Billon et al. 2014). This suggests that attenuation of the rapid pro-inflammatory response generated by increased intracellular $\mathrm{TH}$ levels could be mediated via TR $\alpha$ (Fig. 2A).

\section{Thyroid hormone metabolism in tissue-resident macrophages}

Tissue-resident macrophages can vary widely in phenotype depending on which tissue they are from. $\mathrm{TH}$ metabolism has been specifically investigated in two well-characterized types of tissue-resident macrophages: Kupffer cells and microglia.

Kupffer cells As the resident macrophages of the liver, Kupffer cells are essential for liver homeostasis. This role is enhanced during infection and inflammation. Several studies by the same group have analysed the effect of TH administration on rat liver and the role of Kupffer cells in this process. $T_{3}$ administration induces oxidative stress in the liver (Tapia et al. 1997, 2006, 2010, Valencia et al. 2004, Fernandez et al. 2005, 2007a,b, 2008, 2009). This is thought to be mediated via Kupffer cells, which demonstrate hyperplasia, increased phagocytic capacity, increased ROS generation and tumour necrosis factor $\alpha$ (TNF $\alpha)$ production in response to $\mathrm{T}_{3}$ administration in vivo (Fig. 2B) (Tapia et al. 1997, Valencia et al. 2004, Fernandez et al. 2005, 2007b). Kupffer cell activation by $\mathrm{T}_{3}$ triggers a cascade of responses in the liver including increased TNF $\alpha$ and interleukin-6 (IL-6) levels, which lead to the activation of liver STAT3 phosphorylation and nuclear factor kappa-B (NFkB) DNA binding. This ultimately increases liver iNOS expression and activity

Published by Bioscientifica Ltd. 
together with other markers of oxidative stress including decreased liver glutathione content (an important antioxidant) and higher protein oxidation (Fig. 2B) (Tapia et al. 1997, 2006, Valencia et al. 2004, Fernandez et al. $2005,2007 a, b)$. Conversely, another study found that $\mathrm{T}_{3}$ inhibited STAT3 signalling in macrophages after LPS or IL-6 stimulation and had no effect on TNFo induction and NFkB activation in vitro (Contreras-Jurado et al. 2016). Both acute and chronic inflammation results in increased liver D2 mRNA expression and activity (Kwakkel et al. 2014). This increase occurs independently of changes in serum TH levels and is thought to be caused by increased Kupffer cell activation resulting in higher D2 activity. This suggests that Kupffer cells are also capable of local $\mathrm{T}_{3}$ generation during inflammation, which could be an important mediator in the inflammatory response of these cells (Kwakkel et al. 2014).
The exact pathways through which the effects of $T_{3}$ are mediated in Kupffer cells are still unclear. It is possible that immediate non-genomic actions of $\mathrm{TH}$ are partly attenuated by late genomic TR effects that inhibit the initial pro-inflammatory response to $\mathrm{TH}$ in these cells.

Interestingly, the Kupffer cell-mediated induction of hepatic oxidative stress by $\mathrm{T}_{3}$ appears to ameliorate the harmful effects of ischaemic reperfusion injury in the liver. Hepatic ischaemic reperfusion injury in rats results in severe liver damage (Fernandez et al. 2007a, 2008, 2009, Tapia et al. 2010). These effects were prevented and even reversed by preconditioning with a single dose of $\mathrm{T}_{3}$ (Fernandez et al. 2007a, 2008, 2009, Tapia et al. 2010). The effects of $\mathrm{T}_{3}$ preconditioning were abolished by the addition of treatment with $\mathrm{N}$-acetylcysteine, a powerful antioxidant, suggesting that the protective effect of $\mathrm{T}_{3}$ on liver ischaemic reperfusion injury is achieved through

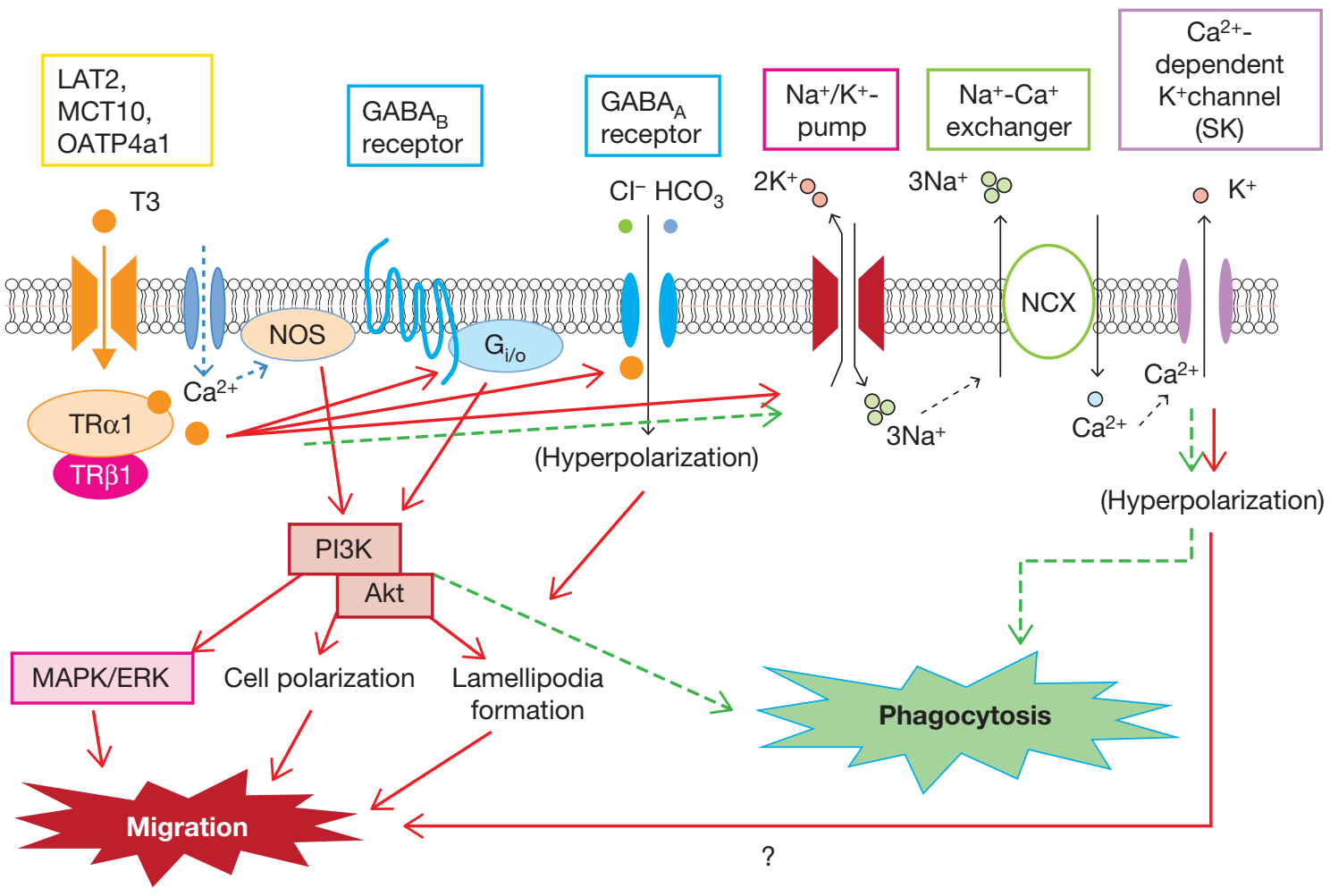

Figure 3

Effects of thyroid hormone on microglia (reproduced with permission from Mori et al. 2015). Schematic representation of possible signal transduction pathways activated by $T_{3}$. Microglia contain various TH transporters (LAT2, OATP4a1 and MCT10) and TH receptors. Intracellular $T_{3}$ activates intracellular TRs (TR 1 and possibly TR $\beta 1$ ) and appears to also couple to various other factors, such as nitric oxide synthase (NOS), G $\mathrm{i}_{/ \circ}$-protein, PI3K and MAP/ERK. The receptors for gamma-aminobutyric acid (GABA) $A$ and $B$ are also involved in $T_{3}$-induced microglial migration but not in $T_{3}$-induced phagocytosis, the mechanism of which is unclear. The reverse mode of the $\mathrm{Na}^{+} / \mathrm{Ca}^{2+}$ exchanger (NCX) may be activated by $\mathrm{Na}^{+}$influx by the $\mathrm{Na}^{+} / \mathrm{K}^{+}$pump, resulting in $\mathrm{Ca}^{2+}$ influx, which in turn activates small-conductance $\mathrm{Ca}^{2+-}$ dependent $\mathrm{K}^{+}$channels (SK). This subsequently induces microglial migration and phagocytosis, possibly due to membrane hyperpolarization. Hypothetical signalling pathways for phagocytosis are indicated by the dotted line. Reproduced, with permission, from Mori Y, Tomonaga D, Kalashnikova A, Furuya F, Akimoto N, Ifuku M, Okuno Y, Beppu K, Fujita K, Katafuchi T, et al. (2015) Effects of 3,3',5-triiodothyronine on microglial functions, Glia, volume 63, pages 906-920. Copyright (2015) Wiley Periodicals, Inc.

http://joe.endocrinology-journals.org DOI: $10.1530 / \mathrm{JOE}-16-0462$
๑ 2017 Society for Endocrinology Printed in Great Britain
Published by Bioscientifica Ltd 
development of transient and reversible oxidative stress (Fernandez et al. 2008, 2009).

Microglia Microglia are the resident macrophages of the central nervous system and are derived from myeloid progenitor cells that migrate to the brain during foetal development (Mass et al. 2016). Due to the neurological phenotype associated with mutations in $\mathrm{TH}$ transporters, intracellular $\mathrm{TH}$ metabolism in brain cells has been assessed in detail. Both murine and human microglia express high levels of LAT2 in addition to MCT10 and OATP4a1, allowing them to transport TH into the cell (Wirth et al. 2009, Braun et al. 2011). In addition, microglia express both $\mathrm{TR} \alpha_{1}$ and $\mathrm{TR} \beta_{1}$ (Lima et al. 2001).

Physiological TH concentrations appear to be crucial for microglial growth and morphological differentiation (Lima et al. 2001). Hypothyroid rats showed delayed microglial growth and differentiation, whereas hyperthyroid animals displayed the opposite phenotype with accelerated microglial growth and differentiation (Lima et al. 2001). A recent study by Mori and coworkers assessed in detail the effects of $\mathrm{T}_{3}$ on microglial activation and the signalling pathways involved (Mori et al. 2015). $\mathrm{T}_{3}$ exposure increased migration, activation and phagocytosis in primary mouse microglia in vitro, indicating a shift towards a more mature and pro-inflammatory phenotype (Mori et al. 2015). These effects were found to be mediated via both genomic and non-genomic pathways (detailed in Fig. 3; reproduced with permission from Mori et al. 2015). Microglial migration and morphological changes associated with cell activation were dependent not only on TH transporters and TRs but also on gamma-aminobutyric acid (GABA)-A and GABA-B receptors, NOS, intracellular $\mathrm{Ca}^{2+}$ influx and G-protein-mediated signalling pathways including phosphoinositide 3-kinase (PI3K) and mitogenactivated protein kinase/extracellular signal-regulated kinase (MAPK/ERK) (Mori et al. 2015). Conversely, the $\mathrm{T}_{3}$-induced stimulation of phagocytosis appeared to be partly mediated by other pathways that did not involve the GABA-A and GABA-B receptors (Mori et al. 2015).

\section{Thyroid hormone metabolism in dendritic cells}

\section{Intracellular thyroid hormone metabolism in dendritic cells}

DCs are known to express TR $\beta 1$ and to a lesser degree TR $\alpha 1$ (Mascanfroni et al. 2008). Furthermore, it was recently

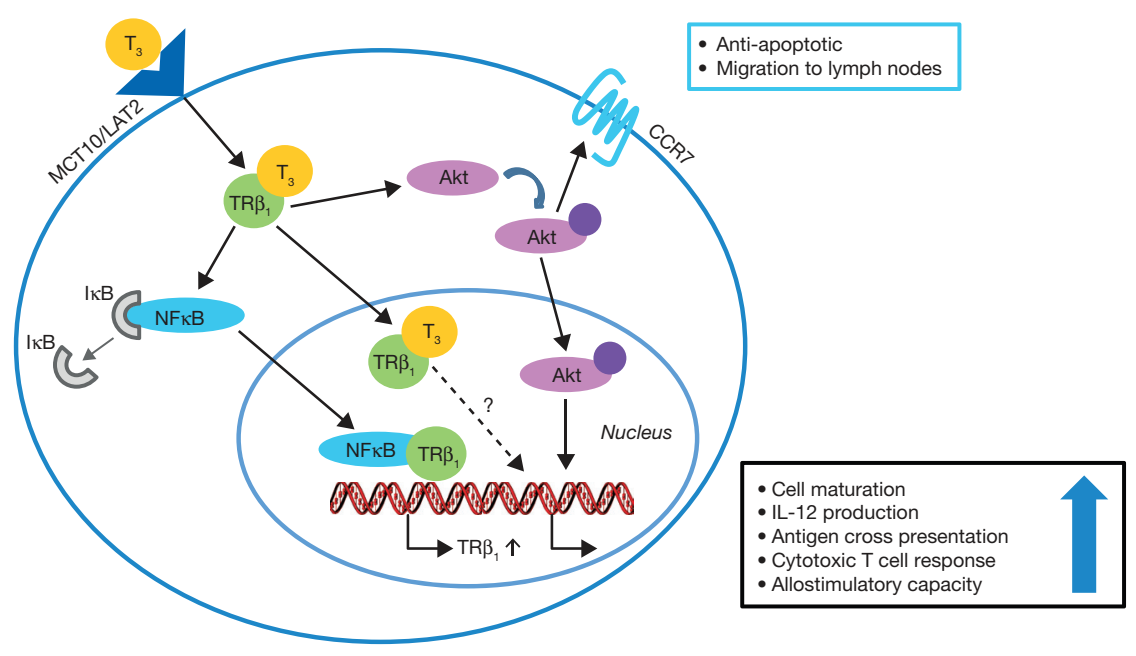

\section{Figure 4}

Thyroid hormone enhances dendritic cell maturation and function. In dendritic cells, $\mathrm{T}_{3}$ enters the cell via TH transporters MCT10 or LAT2 and binds to cytoplasmic TR $\beta 1$ (Gigena et al. 2015 abstract 475, presented at the International Thyroid Congress). Upon binding of $\mathrm{T}_{3}$, TR $\beta 1$ translocates from the

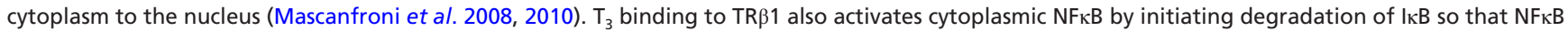
can translocate to the nucleus and regulate gene transcription, including induction of TR $\beta 1$ transcription, which is an NFKB target gene, thus forming a regulatory feedback loop controlling TR $\beta 1$ levels (Mascanfroni et al. 2008). Furthermore, binding of $T_{3}$ to cytoplasmic TR $\beta 1$ activates the Akt pathway, leading to a nuclear shift of phosphorylated Akt and increased chemokine (C-C motif) receptor type 7 (CCR7) expression, which prolongs cell viability and augments cell migration towards lymph nodes (Mascanfroni et al. 2010, Alamino et al. 2015). $T_{3}$ stimulation of DCs shifts the cells towards a more pro-inflammatory phenotype through induction of cell maturation, increased IL-12 production, improved antigen cross presentation and an enhanced ability to stimulate a cytotoxic T-cell response and trigger antigen-specific responses in vivo (Mascanfroni et al. 2008, 2010, Alamino et al. 2015, 2016). 
reported that DCs are capable of active TH transport via transporters MCT10 and LAT2 and exhibit D2 and D3 enzymatic activity (Gigena et al. 2015 abstract 475, presented at the International Thyroid Congress).

\section{Effects of extracellular thyroid hormone levels on dendritic cell function}

TH stimulation has profound effects on DC phenotype. Incubation of human peripheral blood mononuclear cells with TH enhances their ability to differentiate into functional DCs (Mooij et al. 1994). Extensive work by the Pellizas group has shown that stimulation of murine bone marrow-derived DCs with physiological levels of $\mathrm{T}_{3}$ results in the initiation of the adaptive immune response by induction of DC maturation, increased interleukin-12 (IL-12) production, improved antigen cross presentation and enhanced DC ability to stimulate a cytotoxic T-cell response and trigger antigen-specific responses in vivo (Fig. 4) (Mascanfroni et al. 2008, 2010, Alamino et al. 2015). Cell survival and ability to migrate to lymph nodes in vivo are also enhanced (Alamino et al. 2015). The effects of $T_{3}$ stimulation are mediated via the TR $\beta 1$ receptor and the Akt and NFkB pathways independently of the PI3K pathway (Fig. 4) (Mascanfroni et al. 2008, 2010). The promoter region of the TR $\beta 1$ gene contains an $\mathrm{NF \kappa B}$ response element, which upregulates TR $\beta 1$ expression after $T_{3}$ stimulation, suggesting a regulatory feedback loop (Mascanfroni et al. 2010). Dexamethasone potently inhibits and even reverses the effects of $T_{3}$ in DCs (Montesinos et al. 2012).

The effect of $\mathrm{T}_{3}$ on DCs could be beneficial in anticancer vaccines. As DCs are antigen-presenting cells, a patient's own DC can be loaded with tumour antigen ex vivo, inducing DC maturation (Palucka \& Banchereau 2013). The DCs are then re-administered to the patient resulting in a cytotoxic T-cell response against the tumour. Unfortunately, the effects of DC-based vaccines are frequently limited by the short lifespan of activated mature DCs and the risk of immune tolerance (Palucka \& Banchereau 2013). This necessitates the use of costimulatory molecules that increase DC survival and immunogenicity. As $T_{3}$ increases DC survival and DC ability to migrate to lymph nodes, $\mathrm{T}_{3}$ could potentially be of use in DC-based anti-cancer vaccines (Alamino et al. 2016). Indeed, vaccination with $T_{3}$-stimulated DCs in a mouse melanoma model inhibited tumour growth and increased host survival (Alamino et al. 2015).

\section{Summary}

Neutrophils, macrophages and dendritic cells are cells of the innate immune system that are crucial for the host defence against invading pathogens. Thyroid hormone plays an important role in the function of these cells. Neutrophils, macrophages and dendritic cells have all been shown to contain essential elements required for intracellular $\mathrm{TH}$ metabolism and $\mathrm{TH}$ action, including TH transporters, deiodinases and TRs. Furthermore, circulating TH levels strongly affect innate immune cell function. In general, incubation with $\mathrm{TH}$ appears to have a pro-inflammatory effect in these cells. This is illustrated by the fact that ROS production and MPO activity are increased in hyperthyroid neutrophils (Videla et al. 1993, Fernandez \& Videla 1995, Szabo et al. 1996, Magsino et al. 2000, Mezosi et al. 2005, Russo-Carbolante et al. 2005b, Marino et al. 2006). Higher TH levels also increase reactive nitrogen species production, phagocytosis and bacterial killing in macrophages (Forner et al. 1996, Ortega et al. 1996, Chen et al. 2012). In accordance with these effects, $T_{3}$ has been shown to polarize macrophages towards a pro-inflammatory M1 phenotype, whilst inhibiting anti-inflammatory M2 markers (Perrotta et al. 2014). In dendritic cells, TH administration also has pro-inflammatory effects, illustrated by increased cell maturation, pro-inflammatory cytokine production and the increased ability to elicit a cytotoxic T-cell response (Alamino et al. 2015).

Although the effects of circulating thyroid hormone levels on innate immune cells have been studied for decades, the mechanisms involved have only recently been assessed and are currently only partially understood. In all three cell types discussed, there appears to be an interplay of genomic and non-genomic pathways involved in the effects of $\mathrm{TH}$ on cellular function. In neutrophils, extracellular TH appears to induce its pro-inflammatory effects by binding to an unknown G-protein-coupled receptor whose downstream effects are mediated via the protein kinase C pathway (Fig. 1) (Mezosi et al. 2005). In macrophages, another non-genomic pathway has been described involving binding of extracellular $\mathrm{TH}$ to integrin $\alpha v \beta 3$, resulting in activation of the ERK and PI3K signalling pathways (Fig. 2) (Chen et al. 2012). The effects of $\mathrm{T}_{3}$ stimulation in dendritic cells are mediated via $\operatorname{TR} \beta_{1}$ and the Akt and NFkB pathways (Fig. 4) (Mascanfroni et al. 2010). Besides the clear effects of altered extracellular TH levels, recent research has shown that several elements of intracellular $\mathrm{TH}$ metabolism

Published by Bioscientifica Ltd. 
appear to be essential for adequate pro-inflammatory neutrophil and macrophage function. In neutrophils, the thyroid hormone-inactivating enzyme D3 appears to play an important role during infection (Boelen et al. 2005, 2009, van der Spek et al. 2016). D3 induction results in decreased intracellular TH bioavailability and increased $\mathrm{rT}_{3}$ levels, so the role of D3 during bacterial killing may appear contradictory given the effects of exogenous $\mathrm{TH}$ in these cells. However, D3 is a $\mathrm{T}_{3}$-responsive gene that is known to be induced by $\mathrm{T}_{3}$ in other tissues (Hernandez 2005). Whether a similar mechanism is present in neutrophils has not been studied to date, but this could potentially explain the similarity between the effects of higher extracellular TH levels and intracellular D3 activity. In macrophages, both $\mathrm{D} 2$ and $\mathrm{TR} \alpha_{1}$ are required for correct cellular function, which is accordance with the effects of extracellular TH as both these mechanisms result in increased intracellular TH action (Billon et al. 2014, Kwakkel et al. 2014). These studies convincingly demonstrate that adequate regulation of intracellular $\mathrm{TH}$ bioavailability is essential for neutrophil and macrophage function.

\section{Conclusions}

Circulating TH levels have a profound effect on neutrophil, macrophage and dendritic cell function. In general, increased TH levels result in an amplification of the pro-inflammatory response of these cells. Besides a pro-inflammatory effect of extracellular $\mathrm{TH}$, the cellular response to pro-inflammatory stimuli appears to be dependent on functional intracellular TH metabolism, suggesting that TH metabolism plays an important role in host defence against infection. To date, this has best been demonstrated in macrophages.

Future research should focus on the intracellular pathways involved in the modulation of the immune response of innate immune cells by TH. Although a small number of recent promising studies have analysed the pathways that mediate the effects of TH stimulation in innate immune cells and the role of intracellular TH metabolism in innate immune cell function, still relatively little is known about the mechanisms involved. Whether the effects of increased TH levels and the functional role of intracellular TH metabolism in the immune response of these cells are in fact linked and part of the same mechanisms remains to be studied. Studies focussing on these issues would further elucidate the important connection between the endocrine and innate immune systems. This overview of the literature suggests that $\mathrm{TH}$ plays an important role in the host defence against infection through the modulation of innate immune cell function.

\section{Declaration of interest}

The authors declare that there is no conflict of interest that could be perceived as prejudicing the impartiality of this review.

\section{Funding}

A H v d S is supported by the AMC Graduate School PhD Scholarship.

\section{References}

Adelberg HM, Siemsen JK, Jung RC \& Nicoloff JT 1971 Scintigraphic detection of pulmonary bacterial infections with labeled thyroid hormones and pertechnetate. Radiology 99 141-146. (doi:10.1148/99.1.141)

Alamino VA, Mascanfroni ID, Montesinos MM, Gigena N, Donadio AC, Blidner AG, Milotich SI, Cheng SY, Masini-Repiso AM, Rabinovich GA, et al. 2015 Antitumor responses stimulated by dendritic cells are improved by triiodothyronine binding to the thyroid hormone receptor beta. Cancer Research 75 1265-1274. (doi:10.1158/0008-5472.CAN-14-1875)

Alamino VA, Montesinos MM, Rabinovich GA \& Pellizas CG 2016 The thyroid hormone triiodothyronine reinvigorates dendritic cells and potentiates anti-tumor immunity. Oncoimmunology 5 e1064579. (doi:10.1080/2162402X.2015.1064579)

Aoyagi K, Takeshige K \& Minakami S 1991 Effects of iodothyronines on chemotactic peptide-receptor binding and superoxide production of human neutrophils. Biochimica et Biophysica Acta 1093 223-228. (doi:10.1016/0167-4889(91)90126-I)

Baliram R, Chow A, Huber AK, Collier L, Ali MR, Morshed SA, Latif R, Teixeira A, Merad M, Liu L, et al. 2013 Thyroid and bone: macrophagederived TSH-beta splice variant increases murine osteoblastogenesis. Endocrinology 154 4919-4926. (doi:10.1210/en.2012-2234)

Baliram R, Latif R, Morshed SA, Zaidi M \& Davies TF 2016 T3 regulates a human macrophage derived TSH-beta splice variant - implications for human bone biology. Endocrinology 157 3658-3667. (doi:10.1210/ en.2015-1974)

Bardoel BW, Kenny EF, Sollberger G \& Zychlinsky A 2014 The balancing act of neutrophils. Cell Host and Microbe 15 526-536. (doi:10.1016/j. chom.2014.04.011)

Bernal J, Guadano-Ferraz A \& Morte B 2015 Thyroid hormone transporters - functions and clinical implications. Nature Reviews Endocrinology 11 406-417. (doi:10.1038/nrendo.2015.66)

Besedovsky HO \& del Rey A 1996 Immune-neuro-endocrine interactions: facts and hypotheses. Endocrine Reviews 17 64-102. (doi:10.1210/edrv17-1-64)

Bianco AC \& Kim BW 2006 Deiodinases: implications of the local control of thyroid hormone action. Journal of Clinical Investigation 116 2571-2579. (doi:10.1172/JCI29812)

Billon C, Canaple L, Fleury S, Deloire A, Beylot M, Dombrowicz D, Del Carmine P, Samarut J \& Gauthier K 2014 TRalpha protects against atherosclerosis in male mice: identification of a novel anti-inflammatory property for TRalpha in mice. Endocrinology $\mathbf{1 5 5}$ 2735-2745. (doi:10.1210/en.2014-1098)

Boelen A, Kwakkel J, Alkemade A, Renckens R, Kaptein E, Kuiper G, Wiersinga WM \& Visser TJ 2005 Induction of type 3 deiodinase activity in inflammatory cells of mice with chronic local

cientifica Ltd. 
inflammation. Endocrinology 146 5128-5134. (doi:10.1210/ en.2005-0608)

Boelen A, Boorsma J, Kwakkel J, Wieland CW, Renckens R, Visser TJ, Fliers E \& Wiersinga WM 2008 Type 3 deiodinase is highly expressed in infiltrating neutrophilic granulocytes in response to acute bacterial infection. Thyroid 18 1095-1103. (doi:10.1089/ thy.2008.0090)

Boelen A, Kwakkel J, Wieland CW, St Germain DL, Fliers E \& Hernandez A 2009 Impaired bacterial clearance in type 3 deiodinasedeficient mice infected with Streptococcus pneumoniae. Endocrinology 150 1984-1990. (doi:10.1210/en.2008-1133)

Boelen A, Kwakkel J \& Fliers E 2011 Beyond low plasma T3: local thyroid hormone metabolism during inflammation and infection. Endocrine Reviews 32 670-693. (doi:10.1210/er.2011-0007)

Borregaard N 2010 Neutrophils, from marrow to microbes. Immunity 33 657-670. (doi:10.1016/j.immuni.2010.11.011)

Borregaard N \& Cowland JB 1997 Granules of the human neutrophilic polymorphonuclear leukocyte. Blood 89 3503-3521.

Boutzios G \& Kaltsas G 2000 Immune system effects on the endocrine system. In Endotext. Eds LJ De Groot, G Chrousos, K Dungan, A Grossman, JM Hershman, C Koch, M Korbonits, R McLachlan, M New, J Purnell, et al. South Dartmouth, MA, USA: MDtext.com, Inc.

Braun D, Kinne A, Brauer AU, Sapin R, Klein MO, Kohrle J, Wirth EK \& Schweizer U 2011 Developmental and cell type-specific expression of thyroid hormone transporters in the mouse brain and in primary brain cells. Glia 59 463-471. (doi:10.1002/glia.21116)

Brent GA 2012 Mechanisms of thyroid hormone action. Journal of Clinical Investigation 122 3035-3043. (doi:10.1172/JCI60047)

Brinkmann V, Reichard U, Goosmann C, Fauler B, Uhlemann Y, Weiss DS, Weinrauch Y \& Zychlinsky A 2004 Neutrophil extracellular traps kill bacteria. Science 303 1532-1535. (doi:10.1126/science.1092385)

Burger AG, Engler D, Buergi U, Weissel M, Steiger G, Ingbar SH, Rosin RE \& Babior BM 1983 Ether link cleavage is the major pathway of iodothyronine metabolism in the phagocytosing human leukocyte and also occurs in vivo in the rat. Journal of Clinical Investigation $\mathbf{7 1}$ 935-949. (doi:10.1172/JCI110848)

Chen Y, Sjolinder M, Wang X, Altenbacher G, Hagner M, Berglund P, Gao Y, Lu T, Jonsson AB \& Sjolinder H 2012 Thyroid hormone enhances nitric oxide-mediated bacterial clearance and promotes survival after meningococcal infection. PLOS ONE 7 e41445. (doi:10.1371/journal.pone.0041445)

Cheng SY, Leonard JL \& Davis PJ 2010 Molecular aspects of thyroid hormone actions. Endocrine Reviews 31 139-170. (doi:10.1210/ er.2009-0007)

Contreras-Jurado C, Alonso-Merino E, Saiz-Ladera C, Valino AJ, Regadera J, Alemany S \& Aranda A 2016 The thyroid hormone receptors inhibit hepatic interleukin-6 signaling during endotoxemia. Scientific Reports 6 30990. (doi:10.1038/srep30990)

Davis PJ, Goglia F \& Leonard JL 2016 Nongenomic actions of thyroid hormone. Nature Reviews Endocrinology 12 111-121. (doi:10.1038/ nrendo.2015.205)

De Vito P, Incerpi S, Pedersen JZ, Luly P, Davis FB \& Davis PJ 2011 Thyroid hormones as modulators of immune activities at the cellular level. Thyroid 21 879-890. (doi:10.1089/thy.2010.0429)

Fernandez V \& Videla LA 1995 On the mechanism of thyroid hormoneinduced respiratory burst activity in rat polymorphonuclear leukocytes. Free Radical Biology and Medicine 19 359-363. (doi:10.1016/0891-5849(95)00016-Q)

Fernandez V, Tapia G, Varela P \& Videla LA 2005 Redox regulation of thyroid hormone-induced Kupffer cell-dependent IkappaBalpha phosphorylation in relation to inducible nitric oxide synthase expression. Free Radical Research 39 411-418. (doi:10.1080/10715760400029637)

Fernandez V, Castillo I, Tapia G, Romanque P, Uribe-Echevarria S, Uribe M, Cartier-Ugarte D, Santander G, Vial MT \& Videla LA $2007 a$ Thyroid hormone preconditioning: protection against ischemia-reperfusion liver injury in the rat. Hepatology 45 170-177. (doi:10.1002/hep.21476)

Fernandez V, Reyes S, Bravo S, Sepulveda R, Romanque P, Santander G, Castillo I, Varela P, Tapia G \& Videla LA 2007b Involvement of Kupffer cell-dependent signaling in T3-induced hepatocyte proliferation in vivo. Biological Chemistry 388 831-837. (doi:10.1515/ bc.2007.101)

Fernandez V, Tapia G, Varela P, Gaete L, Vera G, Mora C, Vial MT \& Videla LA 2008 Causal role of oxidative stress in liver preconditioning by thyroid hormone in rats. Free Radical Biology and Medicine $\mathbf{4 4}$ 1724-1731. (doi:10.1016/j.freeradbiomed.2008.01.010)

Fernandez V, Tapia G, Varela P, Cornejo P \& Videla LA 2009 Upregulation of liver inducible nitric oxide synthase following thyroid hormone preconditioning: suppression by N-acetylcysteine. Biological Research 42 487-495. (doi:10.4067/s0716-97602009000400010)

Flamant F 2016 Futures challenges in thyroid hormone signaling research. Frontiers in Endocrinology 7 58. (doi:10.3389/ fendo.2016.00058)

Forner MA, Barriga C \& Ortega E 1996 Exercise-induced stimulation of murine macrophage phagocytosis may be mediated by thyroxine. Journal of Applied Physiology 80 899-903.

Freemerman AJ, Johnson AR, Sacks GN, Milner JJ, Kirk EL, Troester MA, Macintyre AN, Goraksha-Hicks P, Rathmell JC \& Makowski L 2014 Metabolic reprogramming of macrophages: glucose transporter 1 (GLUT1)-mediated glucose metabolism drives a proinflammatory phenotype. Journal of Biological Chemistry 289 7884-7896. (doi:10.1074/jbc.M113.522037)

Galvan-Pena S \& O’Neill LA 2014 Metabolic reprograming in macrophage polarization. Frontiers in Immunology 5 420. (doi:10.3389/ fimmu.2014.00420)

Gigena N, Alamino VA, Montesinos MM, Nazar M, Louzada RA, Wajner SM, Maia AL, Masini-Repiso AM, Carvalho DM, Cremaschi GA, et al. 2015 15th international thyroid congress program and meeting abstracts. Thyroid 25 (Supplement 1) P1-A337. (doi:10.1089/thy.2015.29004.abstracts)

Ginhoux F \& Jung S 2014 Monocytes and macrophages: developmental pathways and tissue homeostasis. Nature Reviews Immunology 14 392-404. (doi:10.1038/nri3671)

Harris AR, Christianson D, Smith MS, Fang SL, Braverman LE \& Vagenakis AG 1978 The physiological role of thyrotropin-releasing hormone in the regulation of thyroid-stimulating hormone and prolactin secretion in the rat. Journal of Clinical Investigation $\mathbf{6 1}$ 441-448. (doi:10.1172/JCI108955)

Hashimoto D, Chow A, Noizat C, Teo P, Beasley MB, Leboeuf M, Becker CD, See P, Price J, Lucas D, et al. 2013 Tissue-resident macrophages self-maintain locally throughout adult life with minimal contribution from circulating monocytes. Immunity $\mathbf{3 8}$ 792-804. (doi:10.1016/j.immuni.2013.04.004)

Hernandez A 2005 Structure and function of the type 3 deiodinase gene. Thyroid 15 865-874. (doi:10.1089/thy.2005.15.865)

Hume DA 2008 Macrophages as APC and the dendritic cell myth. Journal of Immunology 181 5829-5835. (doi:10.4049/jimmunol.181.9.5829)

Hume DA 2015 The many alternative faces of macrophage activation. Frontiers in Immunology 6 370. (doi:10.3389/fimmu.2015.00370)

Jirasakuldech B, Schussler GC, Yap MG, Drew H, Josephson A \& Michl J 2000 A characteristic serpin cleavage product of thyroxine-binding globulin appears in sepsis sera. Journal of Clinical Endocrinology and Metabolism 85 3996-3999. (doi:10.1210/jcem.85.11.6966)

Klebanoff SJ 1967 Iodination of bacteria: a bactericidal mechanism. Journal of Experimental Medicine 126 1063-1078. (doi:10.1084/ jem.126.6.1063)

Klebanoff SJ \& Green WL 1973 Degradation of thyroid hormones by phagocytosing human leukocytes. Journal of Clinical Investigation 52 60-72. (doi:10.1172/JCI107174)

Klein JR 2006 The immune system as a regulator of thyroid hormone activity. Experimental Biology and Medicine 231 229-236. 
Kolaczkowska E \& Kubes P 2013 Neutrophil recruitment and function in health and inflammation. Nature Reviews Immunology 13 159-175. (doi:10.1038/nri3399)

Kwakkel J, Surovtseva OV, de Vries EM, Stap J, Fliers E \& Boelen A 2014 A novel role for the thyroid hormone-activating enzyme type 2 deiodinase in the inflammatory response of macrophages. Endocrinology 155 2725-2734. (doi:10.1210/en.2013-2066)

Lima FR, Gervais A, Colin C, Izembart M, Neto VM \& Mallat M 2001 Regulation of microglial development: a novel role for thyroid hormone. Journal of Neuroscience 21 2028-2038.

Lourbopoulos A, Mourouzis I, Karapanayiotides T, Nousiopoulou E, Chatzigeorgiou S, Mavridis T, Kokkinakis I, Touloumi O, Irinopoulou T, Chouliaras K, et al. 2014 Changes in thyroid hormone receptors after permanent cerebral ischemia in male rats. Journal of Molecular Neuroscience 54 78-91. (doi:10.1007/s12031-014-0253-3)

Magsino CH Jr, Hamouda W, Ghanim H, Browne R, Aljada A \& Dandona P 2000 Effect of triiodothyronine on reactive oxygen species generation by leukocytes, indices of oxidative damage, and antioxidant reserve. Metabolism 49 799-803. (doi:10.1053/meta.2000.6263)

Mancini A, Di Segni C, Raimondo S, Olivieri G, Silvestrini A, Meucci E \& Curro D 2016 Thyroid hormones, oxidative stress, and inflammation. Mediators of Inflammation 2016 6757154. (doi:10.1155/2016/6757154)

Marino F, Guasti L, Cosentino M, De Piazza D, Simoni C, Piantanida E, Cimpanelli M, Klersy C, Bartalena L, Venco A, et al. 2006 Thyroid hormone regulation of cell migration and oxidative metabolism in polymorphonuclear leukocytes: clinical evidence in thyroidectomized subjects on thyroxine replacement therapy. Life Science 78 1071-1077. (doi:10.1016/j.lfs.2005.06.016)

Mascanfroni I, Montesinos Mdel M, Susperreguy S, Cervi L, Ilarregui JM, Ramseyer VD, Masini-Repiso AM, Targovnik HM, Rabinovich GA \& Pellizas CG 2008 Control of dendritic cell maturation and function by triiodothyronine. FASEB Journal 22 1032-1042. (doi:10.1096/fj.078652 com)

Mascanfroni ID, Montesinos Mdel M, Alamino VA, Susperreguy S, Nicola JP, Ilarregui JM, Masini-Repiso AM, Rabinovich GA \& Pellizas CG 2010 Nuclear factor (NF)-kappaB-dependent thyroid hormone receptor beta1 expression controls dendritic cell function via Akt signaling. Journal of Biological Chemistry 285 9569-9582. (doi:10.1074/jbc.M109.071241)

Mass E, Ballesteros I, Farlik M, Halbritter F, Gunther P, Crozet L, JacomeGalarza CE, Handler K, Klughammer J, Kobayashi Y, et al. 2016 Specification of tissue-resident macrophages during organogenesis. Science 353 aaf4238. (doi:10.1126/science.aaf4238)

Mezosi E, Szabo J, Nagy EV, Borbely A, Varga E, Paragh G \& Varga Z 2005 Nongenomic effect of thyroid hormone on free-radical production in human polymorphonuclear leukocytes. Journal of Endocrinology 185 121-129. (doi:10.1677/joe.1.05968)

Miot F, Dupuy C, Dumont J \& Rousset B 2015 Chapter 2 Thyroid hormone synthesis and secretion. In Endotext. Eds LJ De Groot, P Beck-Peccoz, G Chrousos, K Dungan, A Grossman, JM Hershman, C Koch, R McLachlan, M New, R Rebar, et al. South Dartmouth, MA, USA: MDtext.com, Inc.

Montesinos MM, Alamino VA, Mascanfroni ID, Susperreguy S, Gigena N, Masini-Repiso AM, Rabinovich GA \& Pellizas CG 2012 Dexamethasone counteracts the immunostimulatory effects of triiodothyronine (T3) on dendritic cells. Steroids 77 67-76. (doi:10.1016/j.steroids.2011.10.006)

Mooij P, Simons PJ, de Haan-Meulman M, de Wit HJ \& Drexhage HA 1994 Effect of thyroid hormones and other iodinated compounds on the transition of monocytes into veiled/dendritic cells: role of granulocyte-macrophage colony-stimulating factor, tumour-necrosis factor-alpha and interleukin-6. Journal of Endocrinology 140 503-512. (doi:10.1677/joe.0.1400503)

Mori Y, Tomonaga D, Kalashnikova A, Furuya F, Akimoto N, Ifuku M, Okuno Y, Beppu K, Fujita K, Katafuchi T, et al. 2015 Effects of 3,3',5-triiodothyronine on microglial functions. Glia 63 906-920. (doi:10.1002/glia.22792)

Mullur R, Liu YY \& Brent GA 2014 Thyroid hormone regulation of metabolism. Physiological Reviews 94 355-382. (doi:10.1152/ physrev.00030.2013)

Murray PJ \& Wynn TA 2011 Protective and pathogenic functions of macrophage subsets. Nature Reviews Immunology 11 723-737. (doi:10.1038/nri3073)

Ortega E, Rodriguez MJ, Barriga C \& Forner MA 1996 Corticosterone, prolactin and thyroid hormones as hormonal mediators of the stimulated phagocytic capacity of peritoneal macrophages after highintensity exercise. International Journal of Sports Medicine 17 149-155. (doi:10.1055/s-2007-972824)

Ortega E, Forner MA, Garcia JJ, Rodriguez AB \& Barriga C 1999 Enhanced chemotaxis of macrophages by strenuous exercise in trained mice: thyroid hormones as possible mediators. Molecular and Cellular Biochemistry 201 41-47. (doi:10.102 3/A:1007020804138)

Palucka K \& Banchereau J 2013 Dendritic-cell-based therapeutic cancer vaccines. Immunity 39 38-48. (doi:10.1016/j.immuni.2013.07.004)

Pearce EJ \& Everts B 2015 Dendritic cell metabolism. Nature Reviews Immunology 15 18-29. (doi:10.1038/nri3771)

Perrotta C, Buldorini M, Assi E, Cazzato D, De Palma C, Clementi E \& Cervia D 2014 The thyroid hormone triiodothyronine controls macrophage maturation and functions: protective role during inflammation. American Journal of Pathology 184 230-247. (doi:10.1016/j.ajpath.2013.10.006)

Pizzagalli F, Hagenbuch B, Stieger B, Klenk U, Folkers G \& Meier PJ 2002 Identification of a novel human organic anion transporting polypeptide as a high affinity thyroxine transporter. Molecular Endocrinology 16 2283-2296. (doi:10.1210/me.2001-0309)

Rosa LF, Safi DA \& Curi R 1995 Effect of hypo- and hyperthyroidism on the function and metabolism of macrophages in rats. Cell Biochemistry and Function 13 141-147. (doi:10.1002/cbf.290130211)

Russo-Carbolante EM, Azzolini AE, Polizello AC, de Assis-Pandochi AI \& Lucisano-Valim YM 2005a Propylthiouracil and thiamazole do not alter in vitro neutrophil oxidative burst. Metabolism 54 300-305. (doi:10.1016/j.metabol.2004.09.009)

Russo-Carbolante EM, Polizzelo AC, Azzolini AE, Maciel LM \& LucisanoValim YM 2005b Neutrophils from Brazilian patients with Graves' disease: some biochemical and functional aspects. Cell Biochemistry and Function 23 297-306. (doi:10.1002/cbf.1164)

Satpathy AT, Wu X, Albring JC \& Murphy KM 2012 Re(de)fining the dendritic cell lineage. Nature Immunology 13 1145-1154. (doi:10.1038/ni.2467)

Schaefer JS \& Klein JR 2011 Immunological regulation of metabolism - a novel quintessential role for the immune system in health and disease. FASEB Journal 25 29-34. (doi:10.1096/fj.10-168203)

Shi C \& Pamer EG 2011 Monocyte recruitment during infection and inflammation. Nature Reviews Immunology 11 762-774. (doi:10.1038/ nri3070)

Szabo J, Foris G, Mezosi E, Nagy EV, Paragh G, Sztojka I \& Leovey A 1996 Parameters of respiratory burst and arachidonic acid metabolism in polymorphonuclear granulocytes from patients with various thyroid diseases. Experimental and Clinical Endocrinology and Diabetes 104 172-176. (doi:10.1055/s-0029-1211440)

Tapia G, Pepper I, Smok G \& Videla LA 1997 Kupffer cell function in thyroid hormone-induced liver oxidative stress in the rat. Free Radical Research 26 267-279. (doi:10.3109/10715769709097805)

Tapia G, Fernandez V, Pino C, Ardiles R \& Videla LA 2006 The acutephase response of the liver in relation to thyroid hormone-induced redox signaling. Free Radical Biology and Medicine 40 1628-1635. (doi:10.1016/j.freeradbiomed.2005.12.033)

Tapia G, Santibanez C, Farias J, Fuenzalida G, Varela P, Videla LA \& Fernandez V 2010 Kupffer-cell activity is essential for thyroid http://joe.endocrinology-journals.org

DOI: 10.1530/JOE-16-0462
๑) 2017 Society for Endocrinology Printed in Great Britain 
hormone rat liver preconditioning. Molecular and Cellular Endocrinology 323 292-297. (doi:10.1016/j.mce.2010.03.014)

Valencia C, Cornejo P, Romanque P, Tapia G, Varela P, Videla LA \& Fernandez V 2004 Effects of acute lindane intoxication and thyroid hormone administration in relation to nuclear factor-kappaB activation, tumor necrosis factor-alpha expression, and Kupffer cell function in the rat. Toxicology Letters 148 21-28. (doi:10.1016/j. toxlet.2003.12.003)

van der Spek AH, Bloise FF, Tichgelaar W, Dentice M, Salvatore D, van der Wel NN, Fliers E \& Boelen A 2016 The thyroid hormone inactivating enzyme type 3 deiodinase is present in bactericidal granules and the cytoplasm of human neutrophils. Endocrinology 157 3293-3305. (doi:10.1210/en.2016-1103)

Vats D, Mukundan L, Odegaard JI, Zhang L, Smith KL, Morel CR, Wagner RA, Greaves DR, Murray PJ \& Chawla A 2006 Oxidative metabolism and PGC-1beta attenuate macrophage-mediated inflammation. Cell Metabolism 4 13-24. (doi:10.1016/j. cmet.2006.05.011)

Videla LA, Correa L, Rivera M \& Sir T 1993 Zymosan-induced luminolamplified chemiluminescence of whole blood phagocytes in experimental and human hyperthyroidism. Free Radical Biology and Medicine 14 669-675. (doi:10.1016/0891-5849(93)90149-O)

Vincent BH, Montufar-Solis D, Teng BB, Amendt BA, Schaefer J \& Klein JR 2009 Bone marrow cells produce a novel TSHbeta splice variant that is upregulated in the thyroid following systemic virus infection. Genes and Immunity 10 18-26. (doi:10.1038/gene.2008.69)

Visser TJ 2016 Cellular uptake of thyroid hormones. In Endotext. Eds LJ De Groot, G Chrousos, K Dungan, A Grossman, JM Hershman, C Koch, M Korbonits, R McLachlan, M New, J Purnell, et al. South Dartmouth, MA, USA: MDtext.com, Inc.

Visser TJ \& Peeters RP 2012 Metabolism of thyroid hormone. In Endotext. Eds LJ De Groot, P Beck-Peccoz, G Chrousos, K Dungan, A Grossman, JM Hershman, C Koch, R McLachlan, M New, R Rebar, et al. South Dartmouth, MA, USA: MDtext.com, Inc.
Weiss G \& Schaible UE 2015 Macrophage defense mechanisms against intracellular bacteria. Immunological Reviews 264 182-203. (doi:10.1111/imr.12266)

Wirth EK, Roth S, Blechschmidt C, Holter SM, Becker L, Racz I, Zimmer A, Klopstock T, Gailus-Durner V, Fuchs H, et al. 2009 Neuronal 3',3,5-triiodothyronine (T3) uptake and behavioral phenotype of mice deficient in Mct8, the neuronal T3 transporter mutated in AllanHerndon-Dudley syndrome. Journal of Neuroscience 29 9439-9449. (doi:10.1523/JNEUROSCI.6055-08.2009)

Woeber KA 1971 Alterations in thyroid hormone economy during acute infection with Diplococcus pneumoniae in the rhesus monkey. Journal of Clinical Investigation $50378-387$. (doi:10.1172/JCI106505)

Woeber KA 1976 A granule-associated L-thyroxine deiodinating system in the human leukocyte. Endocrinology 98 802-806. (doi:10.1210/endo98-3-802)

Woeber KA 1977 Observations concerning the binding of L-triiodothyronine in the human polymorphonuclear leukocyte. Journal of Clinical Endocrinology and Metabolism 44 62-68. (doi:10.1210/jcem-44-1-62)

Woeber KA 1978 L-triiodothyronine and L-reverse-triiodothyronine generation in the human polymorphonuclear leukocyte. Journal of Clinical Investigation 62 577-584. (doi:10.1172/JCI109163)

Woeber KA \& Ingbar SH 1973 Metabolism of L-thyroxine by phagocytosing human leukocytes. Journal of Clinical Investigation 52 1796-1803. (doi:10.1172/JCI107361)

Woeber KA, Doherty GF \& Ingbar SH 1972 Stimulation by phagocytosis of the deiodination of L-thyroxine in human leukocytes. Science $\mathbf{1 7 6}$ 1039-1041. (doi:10.1126/science.176.4038.1039)

Wu SY, Green WL, Huang WS, Hays MT \& Chopra IJ 2005 Alternate pathways of thyroid hormone metabolism. Thyroid $15943-958$. (doi:10.1089/thy.2005.15.943)

Zhu L, Zhao Q, Yang T, Ding W \& Zhao Y 2015 Cellular metabolism and macrophage functional polarization. International Reviews of Immunology 34 82-100. (doi:10.3109/08830185.2014.969421)

Received in final form 4 November 2016

Accepted 13 November 2016

Accepted Preprint published online 16 November 2016
๑) 2017 Society for Endocrinology Printed in Great Britain 